\title{
Conflict Cultural Spaces and Hybrid Identities in Zakes Mda's The Heart of Redness and Jamaica Kincaid's Annie John
}

\author{
Arnold TUMASANG NGWA
}

University of Dschang, Cameroon

\begin{abstract}
This paper examines conflict and the establishment of hybrid identities in Zakes Mda's The Heart of Redness and Jamaica Kincaid's Annie John. The study stems from the premise that colonialist ideologies and discourses have adversely affected relationships between the north and the south. From a colonialist perspective, the multicultural configuration of the world skews the Eurocentric move towards the establishment of Western enlightenment in colonial and post-colonial societies. As seen in the novels, the colonial setting becomes a conflict space because colonialism is simultaneously accompanied by psychological or coercive resistance. The colonized resists the discourses that described them as inferior and they also rejected their dehumanization and exploitation by the colonizers. Discourses about the inferiority of colonized people are continuously resisted because the colonized also have a culture which they consider superior to the cultures of the colonizers. These oppositional views create conflict. However, there is the need to gaze into the idyllic precolonial societies free from all abhorrent colonialist ideologies and practices. Thus, the realization that cultural tolerance and adaptation are ideal in the face of discrimination and xenophobia reshaped the manner in which African literary writers and critics perceived and conceived their relationship with their 'former' colonial masters. This paper probes into the discursive ways in which Zakes Mda and Jamaica Kincaid deconstruct the obnoxious inter-human relationships in their societies. The analyses demonstrate that Kincaid and Mda have consistently shifted to the past in order to make positive reflections that can heal their societies of their various predicaments. They have created a composite culture that fuses past indigenous culture with contemporary Western culture.
\end{abstract}

Keyword-ideologies, discourse, multicultural configuration, xenophobia, adaptation, composite culture.

\section{INTRODUCTION}

The paper examines the role of resistance and hybridity in the construction of a new space in the postcolonial Antigua and post-apartheid South African societies. In this contemporary context, differences in race and customs still exist but postcolonial writers and critics seek sites that can reconcile humanity. It is against this backdrop that this paper probes into the potency of these sites in this contemporary setting where humanity must learn to adopt fraternity as the only option towards the elimination of xenophobic behavior. In the novels, characters create utilitarian and future spaces through recourse to the past (mainly the pre-colonial epoch and to a lesser extent the colonial epoch) to adopt strategies such as adaptation, tolerance and reconciliation. The past in the African cosmology is the 'Macro-Time' or the 'Big Time' which overlaps with the present (and the near future) and makes them inseparable. From this perspective, the present 'feeds' or disappears into the past. According to the African perception of time, "the golden age lies in the past" which is relied upon for the perception and determination of the future (Mbiti 1989: 22-23). This paper, which is based mainly on the attitudes of characters in the face of repression as presented in Kincaid's Annie John and Mda's The Heart of Redness is divided into two parts. The first part examines the role of conflict in the construction of a future space. The second section discusses the role of hybrid characters in the reconciliation of binaries in these spaces presented in the novels.

\section{Statement of the Problem}

The establishment of binaries in colonial settings sparked off conflicts between the colonized peoples and their colonizers as presented in the novels of Zakes Mda and Jamaica Kincaid. Colonialism was aimed at establishing a mono-cultural society dominated by Eurocentric ideologies. At independence African and Caribbean writers and critics started deconstructing these discriminatory discourses while advocating for the recognition and a return to pre-colonial Africa where 
oneness and harmony existed. However, the reestablishment of a pre-colonial Africa free from all Western ideologies and practices could not be a very welcome ideal given the multicultural configuration of the world. The realization that cultural tolerance and adaptation are ideal in the face of discrimination and xenophobia reshaped the manner in which African literary writers and critics perceived and conceived their relationship with their 'former' colonial masters. It is on this premise that the question has been one to re-examine these literary pieces as ideological objects with the potential to reshape and carve out spaces void of all forms of discrimination and xenophobia. It is against this backdrop that the works of these two authors are examined.

\section{Objectives of the Research}

This paper seeks to examine the discursive ways in which Zakes Mda and Jamaica Kincaid deconstruct binary matrices in post-apartheid South Africa and Antigua in their selected novels. Besides, it shows how these authors erase these binaries and foster intercultural understanding in contexts where discrimination and xenophobia created conflict.

\section{Research Questions}

How do Zakes Mda and Jamaica Kincaid present moments of conflict in the novels under study?

How do Zakes Mda and Jamaica Kaincaid in the selected works seek to establish their imagined/beloved communities void of discrimination?

\section{Research Hypothesis}

This based on the assumption that the construction of a "third space" or a "beloved community" in colonial and post-colonial settings is determined by temporal factors. Consequently, time as perceived from the African perspective becomes a caldron that shapes and determines the outcome of conflicting binary attitudes in

\footnotetext{
1 Josiah Royce (1855-1916) is credited with developing the influential idea of the 'Beloved Community'. According to Royce, the 'Beloved Community' derives from the collectivity of individuals who have organized their lives by adhering and acting in service to a central purpose. The challenge for the individual is to coordinate desires into a harmonious entity. This coordination creates a self. Each self constitutes a miniature Absolute. The 'Beloved Community' can emerge when the micro-Absolutes coalesce and work together. Royce believed that the emergence of the 'Beloved Community' would bring about stability and peace among humanity. This idea was expanded upon and popularized by Martin Luther King Jr. Toni Morrison employed aspects of the 'Beloved Community' in her novels, especially Song of Solomon (1977), Beloved (1987), Paradise (1998), and Love (2003), (Carmen Gillespie, Critical Companion to Toni Morrison 380).
}

the colonial and post-colonial societies presented in the novels discussed in this paper.

\section{Theoretical Framework of Analysis}

The theoretical approaches used in this study are postcolonial theory and New Historicism. Post colonial theory is applied in the analysis to deconstruct and challenge colonial codes while New Historicism is used to place the texts in their contexts and examine them as historical objects in order to redefine the concept of time in relation to space from an African perspective.

Postcolonial theory refers to a set of critical perspectives in literature that grapple with the legacy of colonial rule. As a literary theory or critical approach, it deals with literature produced in countries that were once, or are now colonies of other countries. It can still be better described in the words of Elleke Boehmer as a literary analytic approach on literature about the "conditions in which colonized peoples seek to take their place forcibly or otherwise as historical subjects" (Colonial and Postcolonial Literature 3). Postcolonial theory further involves analysis of the dilemmas of developing a national identity in the wake of colonial rule, the ways in which writers from colonized countries attempt to articulate and even celebrate their cultural identities and reclaim them from the colonizers. It also considers the way the knowledge of colonized peoples has served the interest of the colonizers and how this knowledge is produced and used and the ways in which the discourse of the colonial powers is used to justify colonialism through the perpetuation of images of the colonized as inferior. Postcolonial theory is a cultural toolbox and Edward Said's book Orientalism is considered to be the theory's founding work. Other advocates of this theory include Homi Bhabha, Gayatri Spivak, Chinua Achebe, Ngugi wa Thiong'o and Frantz Fanon.

The postcolonial critic John Lye (1998) in an online article entitled "Some Issues in Postcolonial Theory" writes that:

Postcolonial theory deals with reading and writing of literature written in previously or currently colonized countries, or literature written in colonizing countries which deals with colonization or colonized peoples. It focuses particularly on the way in which literature by the colonizing culture distorts the experience and realities, and inscribes the inferiority of the colonized people, and also how this literature attempts to articulate their identity and reclaim their past in the face of the past's inevitable otherness. It can also deal with the way literature in colonizing countries appropriates 
the language, images, scenes, traditions and so forth of colonized countries.

This quotation highlights the fact that postcolonial theory deals with literature from previously or currently colonized countries or literature which deals with colonization, and the manner in which this literature attempts to articulate the identity of the colonized. Lye's viewpoint about postcolonial theory is also supported by Bill Ashcroft et al, (1995) when they purport that:

Postcolonial theory involves discussion about experience of various kinds: immigration, slavery, suppression, resistance, representation, difference, race, gender, place and responses to the influential master discourses of imperial Europe such as history, philosophy and linguistics and the fundamental experiences of speaking and writing by which all of these come into being. Postcolonial theory reflects the egregious classification of 'first' and 'third' world and contests the lingering fallacy that the postcolonial is somehow synonymous with the economically underdeveloped. (2-3)

From the claims of these various critics, postcolonial theory basically 'de-centers' assumptions of superiority in any human society. There are several concepts underlying postcolonial theory and for the sake of this study we shall highlight hybridity and its significance to this paper. This is the conceptual space, which the postcolonial theoretician Homi Bhabha refers to as the "third space".

According to Bhabha, the third space is the arena that constitutes the struggle of the dominant groups undertaking to define the identity of the other within a unitary framework, in contexts where cultural and linguistic practices, as well as histories and epistemologies clash. In The Location of Culture, Bhabha writes:

The concept of the third space is submitted as useful for analysing the enunciation, transgression and subversion of dualistic categories going beyond the realm of colonial binary thinking and oppositional positioning. Despite the exposure of the third space to contradictions and ambiguities, it provides a spatial politics of inclusion rather than exclusion that "initiates new signs of identity, and innovative sites of collaboration and contestation." (1)

For Bhabha, hybridity is about the fact that when a new situation, a new alliance formulates itself, it may demand that you should translate your principles, rethink them and extend them. In addition, hybridity provides for a third space of resistance, negotiation, and articulation of new meanings in the face of ambivalences, normalization, and hegemony. Bhabha has conceived the third space as a liminal, in-between space where the established hegemonic and normalizing practices are challenged, re-articulated, and negotiated. This space signifies a resistance to polarization, binaries, labels, and unitary identities. It is a space that is fluid, shifting, and political. In Bhabha's cultural studies, the "third space" has been understood to indicate the place where life in all its ambiguities is exposed, the ambiguities negotiated, and where identity is constructed and re-constructed, resulting in new identities and possibilities.

Bhabha observes that:

The importance of hybridity is not to be able to trace two original moments from which the third emerges, rather, hybridity...is the "third space", which enables other positions to emerge. This third space displaces the histories that constitute it, and sets up new structures of authority. (Identity, Community, Culture, Difference 211)

In order to erase differences and enable the emergence of new cultural and identity definitions, there is need to resist the established and rigid norms that provide limiting views of the other. The 'third space' allows for the interruption and interrogation of restrictive forms of cultural meaning, resulting in the enunciation of new forms of meanings and production. The 'third space' therefore "serves as a corrective to regulative, hegemonic views, and suggests that identity and culture are complex, ambivalent, and negotiable entities, which reject fixity and polarization" (Bhabha, The Location of Culture 1). Bhabha points out that although the third space is one of contradictions, ambiguities, and ambivalences, it enables negotiation of inclusion rather than exclusion and becomes a site for innovation, collaboration, and contestation of dominant colonial discourses. This paper will probe into the examination of characters who reconcile the polarities established by hegemonic matrices and how this trend constructs an affable space for characters.

For new historical literary critics, the literary text, through its representation of human experience at a given time and place, is an interpretation of history. As such, the literary text maps the discourses circulating at the time it was written and is itself one of those discourses. That is, the literary text shaped and was shaped by the discourses circulating in the culture in which it was produced. Likewise, our interpretations of literature are shaped by the culture in which the text is produced.

Lois Tyson, (1998) writes: 
New historicism, which emerged in the late 1970s, rejects both traditional historicism's marginalization of literature and New Criticism's enshrinement of the literary text in a timeless dimension beyond history. For new historical critics, a literary text doesn't embody the author's intention or illustrate the spirit of the age that produced it, as traditional literary historians asserted. Nor are literary texts self-sufficient art objects that transcend the time and place in which they were written, as New Critics believed. Rather, literary texts are cultural artifacts that can tell us something about the interplay of discourses, the web of social meanings, operating in the time and place in which the text was written. And they can do so because the literary text is itself part of the interplay of discourses, a thread in the dynamic web of social meaning. For new historicism, the literary text and the historical situation from which it emerged are equally important because text (the literary work) and context (the historical conditions that New historical and cultural criticism produced it) are mutually constitutive: they create each other. Like the dynamic interplay between individual identity and society, literary texts shape and are shaped by their historical contexts.(291)

Basically, this is an approach that stemmed from a reassessment of the social, intellectual and institutional elements behind and within literary works. The term New Historicism, was used by Wesley Morris in his "Toward a New Historicism" in 1972 but it has been adopted widely after by Stephen Greenblatt who applied it to a series of historical renaissance studies in 1982. According to Ralph Cohen in New Directions in Literary History, a literary work is "an event, an action, a relation established between a reader and what he reads, audiences and performance" (1). This statement means that there is interaction between the reader and the text. Other critics like Robert Weimann assert that the 'pastness' of the work is part of the present meaning and must inform any reading for "there is no getting away from the inevitable tension between the historical and modern points of view" (New Literary History 106). A work of art is therefore influenced by the past although it cannot be read meaningfully without the recognition of its present context. This paper examines the past, otherwise referred to as the African perspective of time in order to show how characters forged a new space by reconciling the present with historical memory.

\section{ANALYSES AND DISCUSSIONS}

\subsection{Contact and Conflict Cultural Spaces}

The contact between the north and the south entails two hegemonic powers in active contention. In such situations, the tendency is for one group to seek to dominate the other and this incites conflict. Colonialism introduced the Western perspective of time and this fragmented the African and Caribbean societies. In Western societies, cultures evolve rapidly due to the changes in historical epochs. In African societies, time is non-linear and there is a continuum from past to present such that culture remains a belief system that stems from a distant past to the contemporary era. Characters are either fighting to protect their cultural heritage in the early days of contact with the colonizers or they are making recourse to an idyllic pre-colonial era at moments when their societies are already segmented by the establishment of colonialism.

Amilcar Cabral highlights the value of culture as an indispensable factor in resisting foreign domination, because imperial domination can only be maintained by a perpetuated, organized repression of the cultural life of the colonized. Consequently, he elaborates on culture as both an important factor in colonial domination and a crucial means to resist colonial domination:

In fact, to take up arms to dominate a people is, above all, to take up arms to destroy, or at least to neutralize, to paralyze, its cultural life. For, with a strong indigenous cultural life, foreign domination cannot be sure of its perpetuation. At any moment, depending on internal and external factors determining the evolution of the society in question, cultural resistance may take on new forms (political, economic, armed) in order fully to contest foreign domination.(Return to the Source 39-40)

What Cabral stresses here is the role colonial conquest has played in the destruction of indigenous culture and the role of this culture in the anti-colonial resistance. Therefore, considering the importance of cultural oppression in imperialist domination, cultural resistance can be seen as a necessary act of a national liberation movement and as "the organized political expression of the culture of the people who are undertaking the struggle" (Ibid). The value of native cultural resistance to foreign domination lies in the fact that culture is a vigorous manifestation of the ideological plane of the physical and historical reality of a society. The imperialist dominating usurpation of the productive forces negates the historical process of the dominated society. Therefore the objective of national 
liberation is to reclaim the indigenes' right to have their own history.

In the analysis of the various texts, this paper makes use of the postcolonial concepts of resistance and representation, and the New Historicist concepts of ideology and history ${ }^{2}$ to show how the status quo of colonialism and other power structures (like patriarchy), which adversely affect some characters in the colonial and post-colonial epochs are being resisted and new spaces reconstructed.

In the presentation of their colonial and postcolonial societies, Mda and Kincaid do not solely lean on moments when colonialist discourse styled the colonized as inferior but also highlight moments when the colonized rejected certain stereotypes and definitions. In the presentation of conflicts in colonial spaces, the authors use mainly flashbacks, vivid descriptions, metaphors and code features like invectives. Zakes Mda's The Heart of Redness revisits the amaXhosa community, examining the lives of this people before and during the moment of contact with the colonialists. Moments of subversion in Annie John are seen when Annie rejects the role assigned to her by the agents of empire. As such, she refuses to mimic the colonialists.

Basically, the goal of the natives in The Heart of Redness is to send away the whites in order to preserve their heritage. The amaXhosas considered themselves a community with their own ways of life and aspirations. Evidently, this desire to preserve their heritage and identity spurred nationalism among the natives. The first instance of conflict between the British and the natives in the novel occurs when the white administrators decide to hunt down prophet Mlanjeni:

Twin-Twin suppressed bitterness in his heart and went with Twin, his father and a group of mounted men to see the Whiteman who called himself the Great White Chief of the Xhosas, Sir Harry Smith. He watched in humiliation as The Great White Chief commanded the elders and even the chiefs to kiss his staff and his boots.

\footnotetext{
${ }^{2}$ Ayila Orkusa in her PhD dissertation, "History in the Works of Helon Habila" argues that "New Historicists tend to follow the post-Lacanian and post-Marxist view of ideology; rather than see ideology as false consciousness, as something that is obscuring one's perception of the truth. New Historicists argue that to recognize your own ideology is like pushing the bus you are riding on, since it is much part of the way you perceive the world and its workings. As concerns history, they reject the Western tendency to write history from the top down (e.g. political history) or in grand narrative strokes. They are instead more concerned with what Lyotard terms petits récits, particularly how such "little narratives" participate in the consolidation and maintenance of the status quo" (35).
}

The Great White Chief was running wild all over the lands of the amaXhosas, doing whatever he liked in the name of Queen Victoria of England. He even deposed Sandile, the king of the amaXhosa. This called the chiefs even those who were Sandile's rivals to rally around the deposed king. The people had had enough of The Great White Chief. Mounted men led by Xikixa went to the Keiskama River to consult with the prophet. Mlanjeni doctored the military men for war so that the guns of the British would shoot hot water instead of bullets. The great war of Mlanjeni had begun.(18-19)

In these early days of contact between the British and the natives, the latter were dehumanized to an extent that there was always pent-up anger against the British intruders. Perpetual inhuman and brutal acts carried out by the British led to the war of prophet Mlanjeni. Apart from the war of Mlanjeni which lasted for three years, every move of the whites in The Heart of Redness is questioned by the Africans who continually see the whites as a threat to the evolution of their cultures and civilizations. In this instance of resistance, the natives are preserving their environment and cultural space from being destroyed by colonialism. Recourse to cultural values entails the establishment of a non-linear time dimension connecting the present with the past.

The Christian imperialism in Jane Eyre is exposed in Kincaid's Annie John as a source of shame in the figure of Ruth, the blond-haired daughter of an English minister. Ruth is the class dunce:

I could see how Ruth felt from looking at her face. Her ancestors had been the masters, while ours had been the slaves. She had such a lot to be ashamed of, and by being with us every day she was always being reminded. We could look everybody in the eye, for our ancestors had done nothing wrong except just sit somewhere, defenseless. [...] I was sure that if our ancestors had gone from Africa to Europe and come upon the people living there, they could have taken a proper interest in the Europeans on first seeing them, and said, "How nice", and then gone home to tell their friends about it. (76)

Annie John is proud because her ancestors have never been slavers. Here, we see her disdain for slavery. She also considers slavery as a very inhuman act such that anyone whose ancestors have been slavers ought to exhibit a lot of shame. Reflecting back into the innocence of her ancestors, she develops pride and courage and this strengthens her desire to resist British imperialism. 
Annie John's meeting with the Red Girl represents the pinnacle of her rebellion against her mother. Annie meets the Red Girl and adores her because the Red Girl seems to be everything that Annie is not. Annie's upbringing is totally different from that of the Red Girl but Annie envies the Red Girl's world, for it is free from "mother" influences. Annie recounts:

The Red Girl and I stood under the guava tree looking each other up and down. What a beautiful thing I saw standing before me. The red hair that I had first seen standing up on her head was matted and tangled; her hands were big and fat, and her fingernails held at least ten anthills of dirt under them. And on top of that, she had such an unbelievable, wonderful smell, as if she had never taken a bath in her whole life.[...]I soon learned this about her: she took a bath only once a week and that was only so that she could be admitted in her grandmother's presence. She didn't like to bathe and her mother didn't force her. She didn't like to comb her hair, though on the first day of school she could put herself out for that. She didn't like to go to Sunday school, and her mother didn't force her. She loved to play marbles, and was so good that only Skerritt boys now played against her. Oh, what an angel she was, and what a heaven she lived in! I, on the other hand took a full bath every morning and a sponge bath every night. [...]I was not allowed to play marbles, and, as for Skerritt boys, that was hardly mentionable.[...] The Red Girl and I walked to the top of the hill behind my house. At the top of the hill was an old lighthouse at one time, but now it was just there for mothers to say to their children, "don't play at the lighthouse," my mother leading the chorus, I am sure. Whenever I did go to the lighthouse behind my mother's back, I would have to gather up all the courage to go to the top, the height made me so dizzy. But now I marched boldly up behind the Red Girl as if at the top were my own room, with all my familiar comforts waiting for me. It went without saying between us that my mother should never know that we had become friends. We planned to meet at the lighthouse in this way every day for the rest of our lives and beyond. I now worshipped the ground her unwashed feet walked on. Just before we parted, she gave me three marbles; they were an ordinary kind, the kind you could buy three for a penny-glass orbs with a tear-shaped drop suspended in the centre. Another secret to keep from my mother! (57-9)

This is the world of the Red Girl that Annie describes above. The Red Girl's mother lets her run around, while doing whatsoever she likes. As Annie spends more time with the Red Girl, she increasingly throws off the rules that she is expected to follow. She becomes a petty thief. She lies consistently to her mother. She masters marbles, a game her mother deplores. These acts of disobedience are an extension of Annie's anger at her mother. By acting up against her, Annie is taking her revenge upon a mother who insists that they are separate people.

Annie's behavior with the Red Girl is also rejection of the dominant British colonial structure at the time. The Red Girl effectively stands outside the structure. She does not partake in the colonial educational system, therefore does not follow its social order as Annie does. The Red Girl does not wear clean European style clothing, as Annie does. She lets her hair grow wild and she climbs up trees. She does not behave in the "civilized" way that Antiguans have come to learn from their British masters. Even the fact that she lacks a proper name and is simply called "Red Girl", a description that could indicate the color of her skin, shows that she stands apart from the governmental system that imposes names and laws upon its subjects. The color of her skin also depicts her Carib Indian origins, and is an indication of her natural unadulterated state. Annie's attempt to be like the Red Girl demonstrates her own desire to throw off the dominant social order imposed by the colonial class and their expectations. It also shows the Caribbean and African non-linear perception of time as her relationship with the Red Girl illustrates the connection with the Caribbean past

\subsection{Contact and the Creation of Hybrid Identities}

Pre-colonial South African and West Indian societies constituted communities that upheld aspects like fraternity, the respect for their historical and cultural heritage and the desire to evolve as a group. However, colonialism brought divisions and fragmented these societies. Members of colonial societies were classified into masters and servants, a classification that fostered oppression and exploitation. The world of the indigenes was disintegrated by capitalist schemes introduced by the Europeans. Consequently, for South Africa and the West Indies to construct nations that must resist destructive influences, members of these societies must forego the colonialist mentality, and erase ethnic and ideological differences. The idea of nationhood is based on the people's desire towards a common goal. Bhabha referring to Renan's idea of nationhood asserts that:

Renan argues that the non-naturalist principle of the modern nation is represented in the will 
to nationhood-not in the prior identities of race, language or territory. It is the will that unifies historical memory and secures presentday consent. (The Location of Culture 150).

This will to invoke historical memory as a means to construct a space of harmony constitutes a reconciliation or merging of aspects of culture with the indicators of progress found in contemporary society. This is the reason why Robert Young in Postcolonialism notes that "the postcolonial world is a place of mixture" (129). Bringing together positive aspects of the past and those of contemporary society deconstructs the polarization created by colonialism.

The construction of hybrid models is based on the interaction of different cultures and the deconstruction of boundaries created by ethnicity, class, sex, age and capitalism. This integration unveils the positive aspects of the past and those of present-day society. This chapter stems from the fact that cultures that fostered communal life in pre-colonial societies were destroyed by colonialism and we will seek avenues of reconciliation between such cultures and certain aspects of contemporary society which encourage development.

In The Heart of Redness, John Dalton and Camagu epitomize new attitudes. They show a behavior which is opposed to what prevails in their violent society. Throughout the novel, these characters introduce African cultural values into their new society. This makes them ambassadors for peace and reconciliation. By refusing to be part of the oppositional factions in their community, they are opening up avenues for the various groups to reconcile, unite and live in harmony. In his article entitled "Cultural Diversity and Cultural Differences", Homi Bhabha emphasizes the interdependence and mutuality of the culture of the colonizer and that of the colonized. Bhabha argues that all cultural systems are constructed in a "third space of enunciation" (Ashcroft et al. 1995:209). This space will be one of an international culture "not based on exoticism...but on the inscription and articulation of culture's hybridity, a space in which we will find those words with which we can speak of ourselves and others. By exploring this third space, we may elude the politics of polarity and emerge as the others of ourselves" (Ibid 209).

In this excerpt, Homi Bhabha purports that a hybrid space of peace and reconciliation can be attained if characters refuse to judge others as different. This space will not be based on the sole respect for exotic values as has been the case in multicultural societies like South Africa and Antigua but it will be based on the people's desire to construct a "third space" that unites the positive aspects of all cultures. In The Heart of Redness, John Dalton and Camagu wish to see their cultural identity develop and they ingeniously place themselves in Bhabha's hybrid category.

John Dalton is one of the white settlers in Qolorha-by-sea. $\mathrm{He}$ is a descendant of the English colonizers. He does not however harbor any feelings of superiority or inferiority because of his Caucasian background. Just like other South Africans (who are black), he is so attached to this land because his greatgrandfather was among the first English colonizers who settled here. He is fully a member of this community and outrightly tells his white friends who are fleeing South Africa after apartheid that: "this is my land. I belong here. It is the land of my forefathers" (139). His claim is supported by natives like Vathiswa, the hotel receptionist who tells Camagu that "Dalton is only white outside. Inside he is a raw umXhosa who still lives in darkness" (67). He is considered by the inhabitants of Qolorha as one of them for he is involved in every aspect of their culture and pays tribute to monuments representing the ancestors and prophets of the amaXhosas. His loyalty and allegiance to prophetess Nongqawuse is seen as he regularly throws coins at her pool and encourages even tourists to do so (96). Nongqawuse remains a significant figure in the antiimperialist struggle of the amaXhosa and today her memory still epitomizes the struggles for cultural and national authenticity of the amaXhosas. John Dalton has also gone through the initiation school and is circumcised according to the customs of the land. "In his youth...he went to the initiation school and was circumcised according to the customs of the amaXhosa people. He therefore knows the secret of the mountain. He is a man" (8).

John Dalton represents national integration and unity. He embodies positive aspects of Western and African cultures and exemplifies the strength that emanates from members of his society if they promote acceptance and reconciliation. Dalton is very much interested in the cultures of the amaXhosas and this leads Camagu to state that Dalton "speaks much better isiXhosa than he'll ever be able to" (57). He has a deep knowledge of the people's language and other cultural values like the respect for elders and marriage norms. His attitude also enables him to live peacefully with the people of Qolorha.

Camagu combines the Western and African cultures as it will be presented below. After spending thirty years in America, he returns to South Africa in the year of the democratic elections to bring his own contribution to the development of the country. He holds a PhD in Communication and Economic Development and has worked with big international organizations. He however, fails to find a job in South Africa as many employers resort to the pretext that he has "too much knowledge 
which is a dangerous thing" (29), and he was absent when the "freedom dance" was performed. These are the difficulties he faces due to the corrupt nature of his country's administrators.

As the marriage between Camagu and Qukezwa is symbolic of the coming together of two worlds, the rituals preceding the marriage are indicative of the differences between those worlds. Camagu and Qukezwa have already agreed to marry, but they have to submit to elaborate proceedings to get permission from her family. There is much confusion as the circumstances are irregular, but Camagu still does his best to appease the elders so that he can marry Qukezwa. Both Camagu, Qukezwa and the elders work together to treat the traditions in such a way that they can fit the circumstances and so the marriage is arranged. The elders laughingly note that "young people like to change tradition" (243). The fact that Camagu and Qukezwa respect these traditions shows that this marriage truly means a merging of Xhosa culture and modern city life. Camagu and Qukezwa decide for themselves that they want to be together and in doing so they go against the customs of the village, but by submitting to the proceedings that normally precede a Xhosa marriage, they do retain the traditions and rituals that express their cultural identity.

In Kincaid's Annie John, the heroine Annie John is quite conscious of the fact that there are positive aspects of her own world which must not be ignored. She contrasts the indignant behavior of the British colonizers with the affable and fraternal attitude of the colonized. In the novel, Annie John makes a contrast between the attitudes of her ancestors and those of the ancestors of the British colonizers. She claims that the ancestors of the British colonizers were hostile to people of other races, unlike her ancestors who "would have taken proper interest on Europeans on first seeing them" (76). This consciousness of the divergent attitudes of the colonizer and the colonized is good grounding for resistance against colonialism in order to re-establish the pre-colonial atmosphere of fraternity in the colonized world. However, this consciousness does not solely develop an urge for subversion but more importantly a space where differences could be discarded and positive aspects of the culture of the colonizer and that of the colonized could be incorporated for the advancement of their society.

Annie's lifestyle shows how much she borrows from her historical past. In the Antiguan society, the colonialists wish to replace the cultural heritage of the colonized but Annie still embodies aspects of her own culture. Her attitude shows that self-assertion cannot be attained if Antiguans fail to consider the positive aspects of both their background and those in the background of the imperialists. Annie John, like many Antiguans now, take part in many activities introduced by colonialism. Annie even highlights one example:

Of course, sometimes, with our teachers and our books, it was hard for us to tell on which side we really now belong-with the masters or the slaves-for it was all history, it was all in the past, and everybody behaved differently now; all of us celebrated Queen Victoria's birthday, even though she had been dead a long time now. (76)

Her first use of "us" and "we" in the passage refers to the colonized Antiguan people who, she believes, have to determine who they are and with whom they should identify. Her second use of "us," however, refers to all the people who celebrate an English monarch's birthday, a group that most certainly includes the English people living in Antigua. The books Annie mentions in the passage, the mirrors in which she is required to study both history and herself, lead her toward a sense of identity that unites her with the colonizers.

Annie now attends the white man's school and goes to Sunday school. However, when she comes back from church on some Sundays Annie and her mother take a ritual bath prescribed by an obeah woman. Annie John refers to this as a special bath in which flowers of many different trees and all sorts of oils were boiled together. They would then sit in a bath in a darkened room with a strange candle burning away. These baths were taken after Annie's mother had consulted with her obeah women and a trusted friend, all of whom confirm that from the look of things their enemies had set bad spirits against them (1415). Annie John and her mother are conscious of the fact that they have a past which is very significant because it greatly contributes to their livelihood. The colonized in Antigua is inevitably a hybrid because consciously or unconsciously, they indulge in activities that expose them to their culture and the culture of the colonizers. The school milieu in Antigua is designed to transform the colonized children such that they should read the world through Western eyes. This is seen through the school curriculum, the extra-curricular activities like religious rites, the anthem, the singing of chants and hymns such as the "Rule Britannia", all aimed at glorifying the British Empire. However, these children come from a background they have not forgotten and it affects and adulterates the transformation process initiated and perpetrated by their British school masters.

When Annie meets the character referred to as the Red Girl, she falls in love with her. She realizes that Western education and religion have set her apart from her people's culture, whereas the Red Girl has not been 
adulterated by colonialism. Annie understands the fact that a true Antiguan identity can only be expressed when the Antiguans acknowledge the fact that they come from a background that is not inferior to that of the Europeans. Annie questions the exotic manners she had been taught which were simply aimed at erasing the culture of the Antiguans. She contrasts these Western manners with those of the Red Girl and concludes thus: "Oh, what an angel she was, and what a heaven she lived in" (58). Annie John however, spends much time with the Red Girl in order to acquire some of her people's attitudes from this 'angel'. The Red Girl represents the freedom and simplicity of pre-colonial times. Her contact with the Red Girl relocates Annie to the pre-colonial Antiguan epoch and by so doing, she reconciles her past with the present society. Such reconciliation enables her to preserve her people's identity in this imperious colonial world.

\section{CONCLUSION}

This study set out to examine conflict and hybridity in the novels of Zakes Mda and Jamaica Kincaid. The first section examines conflicting cultural spaces as presented in the analyses. These conflicts arise because colonized characters question the logic underlying the discourses and attitudes of the colonizers. The second part studied the creation of hybrid identities in the various novels. Kincaid and Mda have consistently shifted to the past in order to make positive reflections that can heal their societies of their various predicaments. They have created a composite culture that fuses past indigenous culture with contemporary Western culture. To address the individualistic nature of contemporary society, these authors have reflected on the pre-colonial past in order to establish a spirit of community in their societies.

\section{REFERENCES}

[1] Ashcroft, Bill, (2001), On Post-colonial Futures: Transformations of Colonial Culture. London: Continuum.

[2] Ashcroft, Bill et al., (1995), (eds), The Postcolonial Studies Reader. London: Routledge.

[3] Bhabha,Homi, (1994), The Location of Culture. London: Routledge

[4] Boehmer,Elleke, (1995), Colonial and Postcolonial Literature. Oxford: Oxford UP.

[5] Cabral, Amilcar, (1973), Return to the Source. New York.

[6] Cohen, Ralph, ed., (1974), New Directions in Literary History. Baltimore: John Hopkins Press.

[7] Fanon, Frantz, (1995), National Culture; in Ashcroft, Gareth Griffiths and Helen Tiffin, (Eds),The Post-colonial Studies Reader. London: Routledge.

[8] JanMohamed, Abdul, (1995), The Economy of Manichean Allegory; in Ashcroft, Gareth Griffiths and Helen Tiffin,
(Eds), The Post-colonial Studies Reader. London: Routledge.

[9] Kavanagh, James, (1999), "Ideology.” In Frank Lentricchia and Thomas Mclaughlin, (Eds) Critical Terms for Literary Study, Frank Chicago: Chicago University Press.

[10] Kincaid, Jamaica, (1985), Annie John. New York: Farrar, Strauss and Giroux.

[11] Lye, John, (1998), "Some Issues in Postcolonial Theory.”03 Nov. 2012.http://www.brockul.ca/english/ courses /4F70/postcol.html

[12] Mbiti, John S., (1989), African Religions and Philosophy. $2^{\text {nd }}$ ed. Edinburgh: Heinemann.

[13] Mda, Zakes, (2000), The Heart of Redness. New York: Farrar, Strauss and Giroux.

[14] Said Edward, (1994), Culture and Imperialism. New York: Vintage.

[15] Tyson, Lois. (2008), Critical Theory Today: A UserFriendly Guide. London: Routledge.

[16] Young, Robert J. C.,(2001), Postcolonialism: An Historical Introduction. Victoria: Blackwell Publishing. 